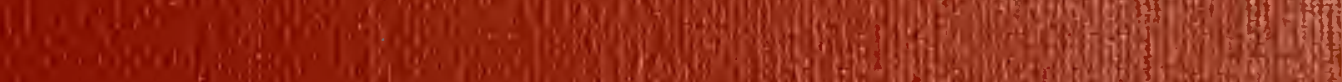

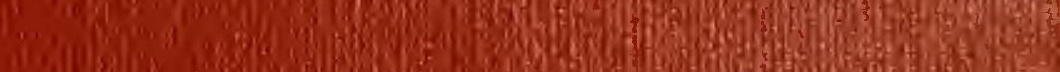

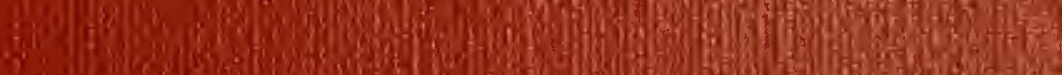
(1),

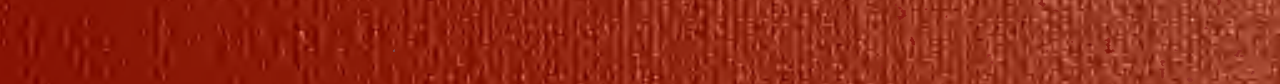
I." H. If 1 If

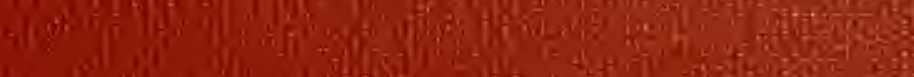

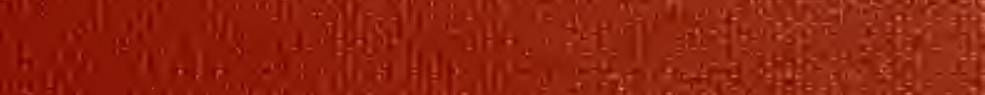
10.4) (n)

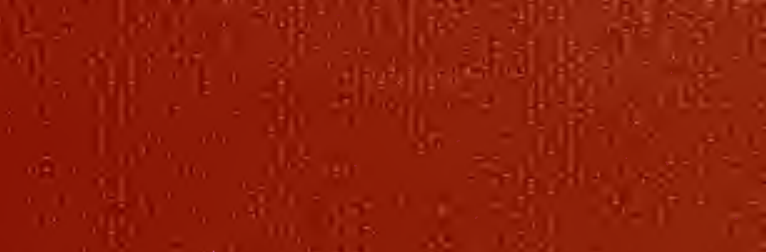

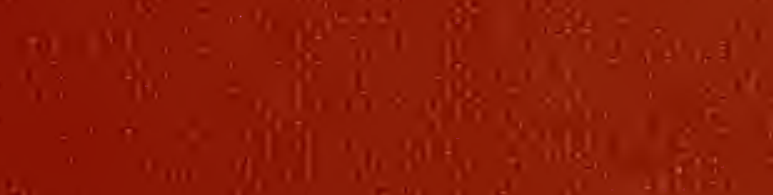

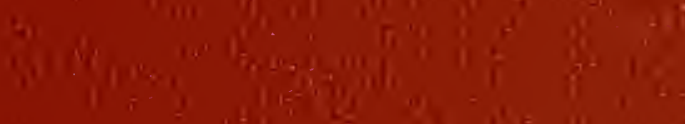

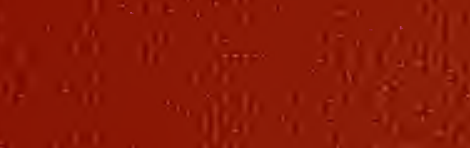

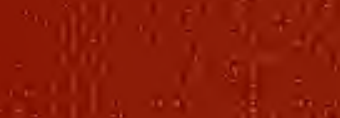

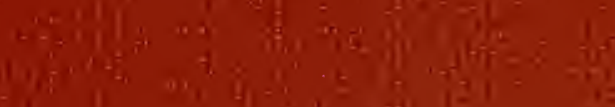

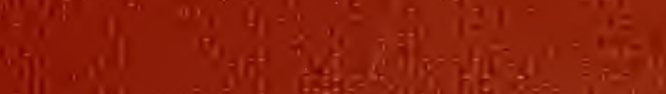

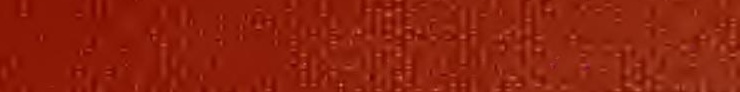

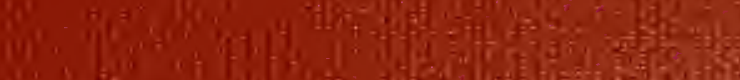

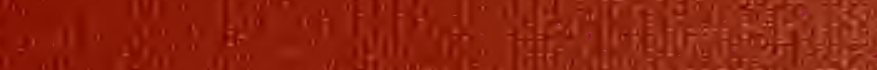
(1).

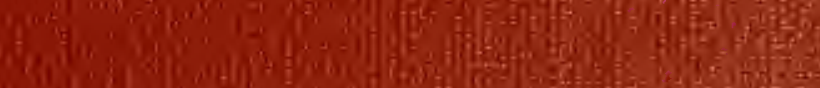

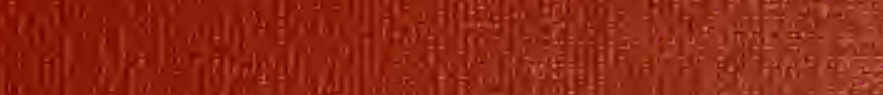
J.

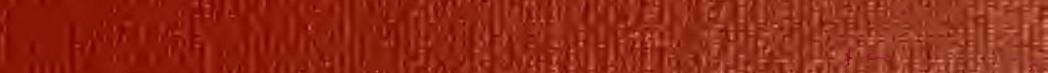

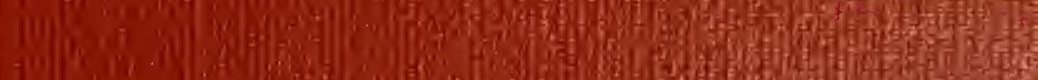

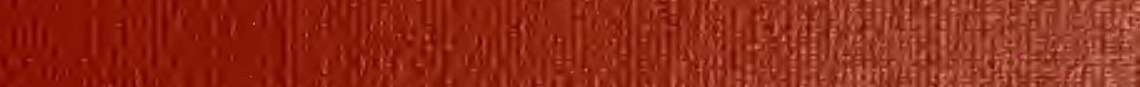
6.

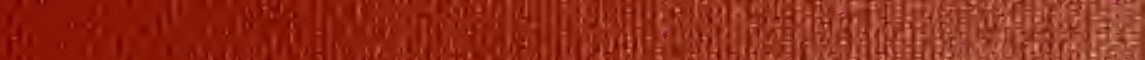
6h. 3 . fin 1. jolo C)

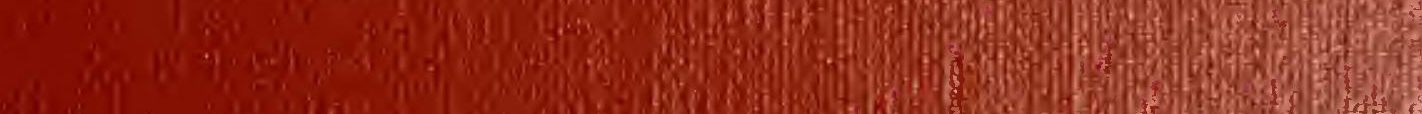





\title{
A SOCIAL ECOLOGICAL BIBLIOGRAPHY
}

\author{
Joel C. Snell and R. Gary Dean \\ Department of Sociology \\ Dana College \\ Blair, Nebraska
}





$$
\begin{gathered}
\text { A. SOCIAL JCOLOGICAI } \\
\text { BIBLIOGRAPHY } \\
\text { by } \\
\text { Joel. C. Snell } \\
\text { and } \\
\text { R: Gary Dean } \\
\text { Dept. of Sociology } \\
\text { Dana College } \\
\text { Blair, Nebraska } 68008
\end{gathered}
$$

Social ecology is a subrield of sociology that incorporates the influences of not only sociology but economics, biology, economics, political science and urban studies. The term "social ecology" was first popularized by Professor Robert Park of the University of Chicago.

This bibliography encompasses literature for urban plenners, ecologists, and urban analysts. Included in the list are such topics as population, environmental polzution, energy shortage, urban crisis, suburban spravi, and city hell politics. The bibliography was originally constructed as background material for a federally funded urban system analysis containing a 50 year projection. 
Aaron, Henry J. Shelter and Subsidies: Tho Benefits from Federal Housing Policies?, 1972.

Abclson, Philip II. "Inergy Conservation," Science, 178:355, 1972.

857, 1973.
isergy and National Security," Science, 179:

Allen, Gary. "Environment: Doomsday and Dictatorship," American Opinion, February 1973, pp. 1-18.

Allied Van Iines, Broadvier, Illinois. Computerized Study $\frac{01}{28}$, the Nation's Migration Patterns $=-1972$, February

Anderson, J. JdTard. "PRT: Urivan Transportation of the Future?" The Futurist, February 1973.

Arbital, Somuel I. Cities and Hetropolitan Areas in Today's Wiorld. Mankato, Minnesota: Creative Educational Society, Inc., 1968.

Hyres, Robert. "Urban Transportation of the Future," The Puturist, August 195́8.

$B$ and $B$ Construction Company. The Euilding Innovations Anonymous Houses on the liove.

Baali, F. and Joseph Vandiver. Urban Sociology -- Contemporary Readings. New York: Appleton-Century-Crofts, 1970.

Banfield, idtrard $\mathrm{C}$. The Unheavenly City: The Nature and Future of Our Uroan Crisis. Boston: Little, Bror!n and Company, 1970.

Beckerman, Wilfred. "The Iivth of the invironnent Catastrophe," National Review, November 24, 1972, pp. 1293-1295.

Beclirith, Buminam P. "Beckrith's 31 Kajor General Social Trands," The Futurist, October 1968, pp. 88-8s.

- "The Future of ivan: Optimism vs. Pessimism," The Futurist, April 1s72, pp. 62-66.

Bell, Daniel. "The Ind of Scarcity?" Society, April 1572, pp. 49-52.

, et al. "Working Session Two: Four Futures," Coirisentary, 1970. 
Bird, Caroline. "Human Rights: Iian is Losing Sone but Gaining Others," The Futurist, February 1973, p. 33.

Black, Angus. A iradical's Guide to Jconomic Reality. New York: Folt, rinehert, Winston, 1970.

Boslioff, Alvin. A Sociology of Urban Regions. ilew York: eppleton-Century-Crofts, 1970.

Brand, David. "Catching Sunbeams -- Old Drean of Putting Suns' Fire to Work Gets Renewed Attention," Wall Street Journal, April 16, 1973, pp. 1, 14.

Bramar, Jack. "Price of Land Soars in a Thirl of Housing," Omaha Vorld-Herald, February 1573.

Brotjer, David, Jolnn Holdren, Mr. Lovins and Jerry Weingart. "Hov to Use Less Energy," Not Man Apart, Vol. II. San Prancisco: Friends of the Tarth, August 1972.

- "Should Atomic Inergy Go Back to the Drawing Board?" Not lian fpart, Vol. II. San Francisco: Friends of the Earth, fiugust 1972 .

Brom, Lester R. "New Grain Seeds are Changing the Outlook for Feeding the World's Spiraling Population, "Foreign Affairs, July 1968.

Bryerton, Gene. Nuclear Dilemma. Ner York: Ballantine Books, Inc., 1970.

Canterberry, I. R. and H. Bickel. "The Green Revolution and the World Rice Iiarket," Imerican Journal of Agricultural Iconorics; Urbana, Inlinois, 1971.

Carson, Rachel. Silent Spring. Boston: Houghton Iiffilin, 1962.

Chapmen, Duane, Timothy Tyrrell and Tinothy Iount. "Ilectricity Demend Growth and the Energy Crisis," Science, 178, 1972, pp. 703-708.

City Planning Commission. City Plan. Omaha, Nebraska, 1946.

Clark, John. "Thermal Pollution and Aquatic Life," Scientiric American, March 1506.

- "Thermal Pollution: 1 Threat to Cayuga's Waters?" Science, 162, pp. 649-0́50. 
Clark, Lindley H., Jr. "Houses on the liove," Vall Street Journal, liay 7, 1973.

Clark, Wilson. "Nixon on Jnergy," INot Man Apart, Vol. II. San Francisco: Friends of the Earth, August 1972.

- "Iluclear Plants are Unsafe," Not ilan Apart, Vol. I. San Francisco: Friends of the Earth, JuIy 1971.

Clawson, Marion and Jack L. Knetsch. "Outdoor Recreation, Resources for the Future Study Foresees Huge Increases," The Futurist, June 1968, pp. 56-57.

Comission on Marine Science. Marine Resources and LegalPolitical Arrangements for Their Development," Engi- . neering and Resources Panel Report, Vol. 3. Washington: U.S. Government Printing Office, 1969.

Commission on Population Growth and the fmerican Future. Population and the American Future. Washington: Federal Government Printing Oflice, 1972.

Commission Report from the Advisory Commission on Intergovernmental Relations. Urban and Rural America: Policies for Future Growth. Washington, April 1968.

Commoner, Barry. Science and Survival. New York: Viking Press, 1969.

Conservation Foundation. Needed: Better Regulation of Pesticides and Integrated Methods of Pest Control. Washington, D.C.

Cook, Jarl. "Inergy Sources for the Future," The Futurist, August 1972, pp. 142-15?.

Cooley, Charles H. Theory of Transportation. Baltimore: Publicators of the American Econoric Association, 1894.

Cooper, Robert. "Euthanasia and the Notion of Death with Dignity," The Christian Century, February 21, 1573, pp. $225-227$.

Cronkite, Walter. "Twenty-First Century, the World You'll Iive In," Popular Science, 190, April 1967, pp. 98-101.

Dean, G. W. and G. A. King. "Projection of California Agriculture to 1980 and 2000: Potential Impact of San Joaquin Valley West Side Development," Giannia Foundation Resource Report of California, Agricultural Experiment Station, Berkeley, 1970.

Demaree, Allan T. "Cars and Cities on a Collisicn Course," Fortune, 81, February 1970, p. 126. 
Downs, Gene G. and Charles P. Norman. Nuclear Power Controversy. Farmingham: Lastern liass. Regional Library System, 1971.

Dyment, Robert. "Transportation: Wheels, Wings and Hulls for the Year 2000," Science Digest, November 1968.

Tditorial Research Section, Office of Public Affairs of the Invironmental Protection Agency. "An Invironmental Bibliography," Washington, 1971.

Idsall, John T. "INuclear Inergy," Science, 178, 1572, p. 933.

Thrlich, Paul. The Population Bomb. New York: Ballantine Boolss, 1968.

and finn H. Whrlich. Population Resources Inviron-

ment. San Francisco: U. J. Freeman, 1970.

and Richard L. Herremon. How to be a Survivor.

iNew York: Valentine Eook, 1971.

and John P. Holdren. "Why Do People Ifove?"

Saturday Revier, September 1970.

Swold, William R., Jr., ed. Environnent and Policy the Iext 50 Years. Indiana University Press, 1968.

- Bnvironment for lian (The Next 50 Years). Inciiana University Press, 1967.

Fair Stand Committee. Federal Viater quality Advice. (Locally Published.)

Feinberg, Gereld. "Long-Range Goals in the Environment," The Futurist, December 1971.

Ferkiss, Victor. Technological Man: The Iiyth and the Reality. George Vraziller Publisher, 1970.

- "Tourard the Creation ô̂ Technological Mian," The Futurist, February 1970, pp. 11-12.

Frisbie, Al. "County Housing Grows in iNumber, Value, Size," Omaha Vorld-Herald, February 14, 1971.

Gannon, Robert. "Atomic Power -- What are the Dangers?" Science Digest, Vol. LXXI. IJew York: The Hearst Corp. 
Geeseman, Donald. "And Now for a Little Diversion ...," Environment, Vol. 14. St. Louis: Scientists' Institute for Public Information, October 1972.

George, P. S. and G. A. King. "Consumer Denend for Food Commodities in the United States with Projection for 1980," Giannini Federal Monograph, California Agricultural Fxperiment Station, Berkeley, California, 1971.

Gerson, Wolfgana. Patterns for Urban Iiving. University of Toronto, 1970 .

Gillette, Robert. "Iuclear Safety: Damaged Fuel Ignites a New Debate in AZC, "Science, 177, 1972, pp. 330-331.

- "Iuclear Safety (I): The Roots of Dissent," Science, 177, 1972, pp. 771-776. - "Nuclear Safety (II): The Years of Delay," Science, 177, 1972, pp. 867-871.

- "Ijuclear Safety (IV): Barriers to Communications," Science, 177, 1972, pp. 1080-1082.

- "Reactor Safety: AIC Concedes Some Points to Its Critics," Science, 178, 1972, pp. 482-484.

- "The Budget of the U.S. Government, 1974: Inergy," Science, 179, 1973, pp. 549-550.

Givens, Richard A. "New Aspirations for Man in the Space Age," The Futurist, October 1969, pp. 118-119.

Gofman, John $\mathrm{H}$. and Arthur R. Tamplin. Poisoned Pover: The Case Against Nuclear Power Plants. Immaus: Rodale Press, Inc., 1971.

Gordon, liitchell. Sick Cities. Baltimore: Penguin Books, 1967.

Grimmer, D. D. and K. Luszczynski. "Lost Power," Environment, Vol. 14. St. Louis: Scientists' Comittee for Public Information, April 1972.

Gullion, Idmund A., ed. Uses of the Seas. Inglerood Cliffs: Prentice-Hall, Inc., 1968.

Hall, Peter. The Forld Cities. New York: NicGraw-Hill, Is69.

Halverson, Guy. "Iiegalopolis Growth Predicted," The Christian Science IIonitor, J anuary 24, 1570, p. 11 . 
Famil, Ralph. "The Future of the Oceans," The Futurist, June 1972, pp. 109-110.

- "Ioving Beyond the Eartin," The Tuturist, April 1071, pp. 58-71.

Harmond, Allen L. "Energy Options: Challenge for the Iuture," Science, 177, 1972, pp. 875-876m.

"Solar Energy: The Largest Resource," Science, 177, 1972, pp. 1088-1090.

- "Fission: The Pro's and Con's of iluclear Poryer," Science, 178, 1972, pp. 147-14.9. - "Conservation of Inergy: The Potential for Niore Efficient Use," Science, 178, $\mathrm{pp}$. 1079-1081.

- "Inergy Needs: Projected Demands and How to Reduce Them:" Science, 178, 1972, pp. 1186-1188.

- Mnergy and the Future: Research Priorities and National Policy," Science, 179, 1973, pp. Iú4-166.

- "Solar Inergy: Proposal for a ilajor Research Program," Science, 179, 1973, p. 11ló.

Hardin, Clifford M. "Steps to Improve Life in Rural Areas," The Futurist, October 1970, pp. 165-166.

Hardin, Garrett. Population Evolution or Birth Control. San Francisco: William H. Freeman Company, 1969.

- Stalking the Wild Taboo. Los Altos: William Feurnenn, Inc., 1973.

Harris, Philip R. "From Evolution to Bmergence," The Futurist, October 1967, pp. 74-75.

Harison, G. A. and A. J. Joyce, eds. The Structure of Human Populations. Clarendon Press, 1972.

Depertment of Health, Education, and Telfare. "Life Tables," Vital Statistics of the United States, Vol. II, Section 5, pp. 5-12, itshington, D.C.

Hersey, Irrin. "We Will Have to Run Very Hard Just to Stay Iven," Ingineering Opportunities, hay 1969. 
Ieningson, Durham and Zichardson (Consultants). "Solid Taste Disposal for the Omaha-Council Bluffs lietropolitan Area Planning kgency," Report, 1969. PIan, JuIy 1972 .

Hickel, Valter J. Who Gms fmerica? Ilev Yorls: PrenticeIlall, 1972.

Hirst, Jric and John C. Moyers. "Jfficiency of Inergy Üse in the United States," Science, 179, 1973, pp. 1299-1304.

Holcomb, Lainy C. and Robert H. Anderson. "Ouality Invirommental Council," Parmphlet. (Locally published.)

Holden, Constance. "New inergy liessage Domplays $R$ and $D$, Science, 180, 1973, p. 475.

Hopkins, Frank Snowden. "The Rise of Technological Iian," The ruturist, February 1970, pp. 12-13.

- "Stuart Chase Eirvisions the 'Host Probable' Torld," The Futurist, Hugust 1568, p. 82.

"The Underdeveloped Countries ijorr Dare to Hope," The Futurist, June 1970, pp. 103-104.

Howerd, Walter. "The Population Crisis is Here Now," Eioscience, Vol. 19, September 1269, p. 783.

Jackson, Charles B. "Teltite Unlocks Secrets from the Ocean's Floor," Netional illdlife, 9:3April-iay 1971, pp. 51-54.

Johnson, Paul. "The Next Huncired Years," Nive Statesman, Iarch 28, 1969, pp. 438-439.

Kammejer, Kenneth U. Population Studies. Rand IicNally, 1970.

Kieffer, Jarold A. "The Automobile's Success: A Lesson for Its Critics," The Futurist, February 1973.

Iillbridge, II. C., R. P. O'Block and P. V. Teplitz. Urban Analysis. Boston: Harvard University, 1970.

Klein, Rudolph. "Grorth and Its Inemies," Comentary, June 1972.

Klemme, Randal T. "Industrial Development -- 2000 A. D.," The Futurist, February 1968. 
Snapp, Clifford $\mathrm{I}$. "Gco-Problems," Instiuctor Publications, 1970.

- "icology Series," Instructor Publications, 1970.

Irraus, Albert I. "The 1960's Should Have Been INo Surprise for the Demographers," New York Times, January 11, 1973.

Kristol, Irving. "Is Jew York City in a Crisis," Social Profile USA Today. New York: Van iJostrand Reinhold Company, 1970 .

Large, David B. "Conserving Energy: Some Things that can be Done," Not Ilan Apart, Vol. III. San Francisco: Friends of the Earti, March 1973.

Levandorska, Z. "Food ileea's and the Reserves of the Agricultural Production Growth Until the Year 2000," Ekonomista, Warszara, 1967.

Lincoln, G. A. "Energy Conservation," Science, 180, 1973, pp. $155-162$.

Lindsey, Robert. "Passengers irill Ride to $70^{\prime} \mathrm{s}$ on Hopes and Problerns," New York Times, January 11, 1970.

Iovenstein, Louis K. Urban Studies. Hew York: Free Press, 1971.

Iiciele, Johit. "Planning the Future," Curreni, September 1909, pp. 16́-25.

licloughlin, J. B. Urban and Regional Planning: A Systems Approach. Nev York: Frederick A. Praeger, 1909.

Molicheel, Stanley and Robert ㅍ. Binghen. City Growth Issentials. Cleveland: Stanley llolichael Publishing Organization, 1928.

Iiaddox, Jolun. Doomsday Syndrome. New York: McGraw-Hill, 1973.

IIAPA Bconomic Base Survey, City Planning Board, Commity Renertal Progran. June 30, 1970. (Locally published.)

Mason, Roy. "Areas Vithin a City Might also Specialize," The Futurist, October 1969, p. 131.

Niaugh, Thonas H., II. "ruel from Tastes: A Minor Energy Source, " Science, 178, 1972, pp. 599-602. 
ilayer, Albert B. The Urgent Future. ITew York: IicGratIill Book Company, 1967.

- "Large Scale Famines are Eecoming Less Iikely, Iutritionists Believe," Columbia University Forurn, 12: 2. Surner 1969.

Miayer, I. V. "in Analysis of Future Resource Supplies, Fesource Utilization, Domestic and Ixport Demand, and Siructural Change in the Agricultural Iconomy to 1980," Dissertation Abstract, 28:4, pp. 1173-1174, Ann Arbor, Iichigan, Order No. 67-12, 979.

llayr, Jarnest. Biological lian in the Year 2000. Cambridge: Harvard University, 1567.

Meadots, Denis L. "ITuclear Inergy and Grotth," Science, 179, 1973, pp. 855-856. 1971, pp. 137-144.

Neadows, Donella, et al. The Limits to Grouth. Hew York: Universe Books, 1970.

Headows, Headows, Randers and Eehrens. "The Limits to Growth," (review by Myron A. Sharp) in Society, September 1972.

Mesthene, Fmmanuel. "Is Technology Destroying Human Values?" The Futurist, August 1969, pp. 94-95.

The lietropolitan Area Planning Agency. Council of Ilected Planners, Comprehensive Planning, 1971. (Lncally published.)

Meyer, John R. "A ZPG Jconomy," Money Magazine, May 1973.

Piiles, Rugus $\Xi$. "Three Ways to Solve the Population Crisis," Man's Population Predicament - - Population Eulletin, 27:2, published by Population Reference Eureau, April 1971.

Miller, David C. "The Environment-liakers," The Futurist, August 1967, pp. 59-60.

Niller, J. Irvin. "Can We Afford Tomorrow? Changing Priorities: Hard Choices, New Price Tags," Staurday Review, January 23, 1971, pp. 36-38.

Nills, T. S. Studies in the Structure of the Urban Economy. Baltimore: Johns Hopkins Press, 1972. 
Iiitchell; J. Wurray, Jr. "Is lian's Industry Upsetting World Veatiner?" The Futurist, April 196\%, pp. 34-35.

Mobile Homes Manufacturers kssociation. Miobile Homes are Rising Rapidly in Popularity in the United States," Chicago.

Nioe, L. T. and M. M. Montadi. "World Supply and Demand Prospects for Cilseeds and Cilseed Products in 1980 with Emphasis on Trade by the Less Developed Countries," Foreign Agric. Econ. Rep. Icon. Serv. U.S. Department of Agriculture, 71, Washington, D.C., IS71.

Irutual of Omaha. Nature's Living Wuseum. (Locally published.)

Nash, Hugh. "Review of Energy by John Holdren and Phillip Herera, " INot Nan Apart, Vol. III. Sen Francisco: Friends of the Barth, February 1973.

National Committee on Urban Growth Policy. The New City. New York: Frederick A. Praeger, 1969.

Nebraskans for Peace. A Primer for People who Care! That You Can do to Save Your Envi ronment! (Locally published.)

Odum, Jugene P., et al. The Crisis of Survival. liedison: Scott, Foresman, and Company, 1970 .

Omaha-Council Bluffs letropolitan Area Planning Agency. "IS70 Housing Study," Report iNo. 110.

Omaha City Planning Board. The Omaha Nebraska Cormunity Renewal Program (Basic Analysis City-Wide Analysis), $\overline{1960 .}$

Organization for Economic Cooperation and Development (OECD), Future Directions for Research in Urban Transportation, (report of panel discussion including Sumner Meyers and others). Publications Office, 2 rue Andre-Pascal, 75 Paris (16e), France, 1969.

Owen, Hilfred and Inai Bradfield. The Accessible City. The Brookings Institution, 1972 .

Palen, John and Carl H. Flaming. Urban fmerica -- Conflict and Change. New York: Hope, Rinehart and Winston, 1972.

Peper, Bram. "Agricultural Policy and Social Policy," Rural Sociology, 9:3, 1969, pp. 221-234. 
Peterson, Villiam. Population. London: Milillan Company, 1969.

Pickard, Jerome P. "Is Iiegalopolis Inevitable?" The Futurist, October 1970, pp. 151-152.

Planned Parenthood. World Population. I!T York, Wew York.

Population Reference Bureau, Inc. The Future Population of the United States. Washington, D.C.

Rand Corporation. "Tand Tarns: Technology offers no short -or Iiiddle-Term Solutions to the 'Energy Crisis,' So Demand for Power liust be Curtailed, "ijot ilan Apart, Vol. III. San Francisco: Friends of the Narth, February 1973.

Rathlesberger, Jim. "Administration Watching -- INuclear Power," Not Man Apart, Vol. I. San Francisco: Friends of the Ierth, October 1971.

Rees, Phillip H. Factoral Ecology of Metropolitan Chicago. Chicago: University of Chicago, 1968.

Reich, Charles A. The Greening of America. Ner York: Random House, 1970.

Reid, Sue Titus and David I. Iyon. Population Crisis and Interdisciplinary Perspective. GIenview: Scott, Foiesman and Company, 1972.

Revelle, Roger and others. The Ocean. San Francisco: W. H. Freeman and Company, 1969.

Roos, Leslie I., Jr., ed. The Politics of Ecosuicide. New York: Holt, Rinehart, ilinston, 1971.

Rosenfeld, Albert. II Gensis - The Coming Control of Iife. Nev York: Prentice-Hall, 1970.

Rrehoda, Robert. Extended Youth: The Promise of Gerontology. - "Our Children liay Iive to be 100 Years 0ld," The Futurist, February 1969, pp. 4-6.

Samuelson, Paul A. "Falling Birth Rates," Nerstreek, June 1s, $1872, \mathrm{p} .75$.

Sartwell, Joyce. "The Coming Decline of the Classroom," The Futurist, April 1969. 
Seaborg, Gleni T. "The Birthpangs of a IJew Vorld," The Futurist, December 1270, pp. 205-208.

- "Some Long-Range Implications of Huclear Inergy," The Futurist, February 1968, pp. 12-13. pp. $157-160$. and Vilizam in. Corlis. ilan and Atom: Building a IJer World Through Nuclear Technology. Nev York: I. P. Dritton and Company, 1971.

Shanas, Ithel. "The Sociology of $\Lambda$ ging and Aged," Sociological ruarterly, Spring 1971, pp. 159-176.

Sharp, Eric. "Seafood Scientists Hoping Experiments Bloom Into Industry," The Omaha World-Heralc, February 25, 1973.

Sheppard, Gene. "The Disaster Lobby on the IJarch," Human Ivents, Farch 6, 1971, pp. 1-4.

Silber, Howard. "The People INovers: Busway ixperiment Looling Good," World-Herald irashington Bureau, Omaha World-Jerald, Iiay 30, 1973.

Silha, Stephen and Susan Vatters. "Supercommunity PIans Ain to Solve Suburban Ills," Christian Science Ionitor, iNovember $30,1972$.

Simoncini, Giorgio. "The Future and the City," Bologna: II Milino, 1970.

Sirjanaki, John. The Jociology of Cities. ITew York: Randorn House, 1904.

Skreja, finton. "The Future Population of the United States," Population Bulletin, spril 1971.

Soleir, Paclo. "Arcology: The City in the Image of IIan," in Annual Editions Readings in Sociology $172-173$ by Dean fcheson, et al. Guilf ord, Connecticut: Dushkin Publishing Group, 1972.

Spengler, J.J. "Economic Grouth in a Stationary Population," Population Reference Burecu, JuIy 1971.

Squires, Arthur Ii. and David A. Burliritz. Poiser of Generation and Invironmental Change. Cambridge: WIT Press, 1971. 
Stanford, Jventin H., ed. The Vorld's Population-Problems of Grouth. Toronto: Oxford University Press, 1972.

Stans, Iaurice. "The U.S. Plain for Curbing Ilegalopolis," The Futurist, October 1970, pp. 157-158.

Stein, Maurice $R$. Jclipse of Conmunity. New York: Herper and $20 \mathrm{~N}, 1960$.

Swatek, Paul. The Users Guide to the Protection of the Invi ronment. Nev York: Valentine Books, 1970.

Taylor, Gordon. The Doornsday Book: Can the Vorld Survive? INev York: World Publishing Compeny, 1971.

Teller, Aaron. "The Only Vay Out of Pollution," The fmerican Legion liagazine, June 1970, pp. 6-11.

Thompson, David. "Hearing is liay 8 on Transport Plan," Onaha iJorld-Herald, April 18, 1973.

- Mass Transit Study Sugfest 4 Routes," Omaha World-Herald, liay 23, 1971.

- "Small Rail Transit 'Ideal for Omaha'," Omaha Jorld-ierald, July 4, 1971.

Thompson, Warren S. and David L. Letiis. Population Problems. iNew York: MicGraw-Hill, 1965.

Tietz, Trederick J. and Janes I. Iickeotran. The Changing Ietropolis. Boston, 1964 .

T'ofrler, Alvin. Future Shock. New York: Random House, 1970 , p. 56.

Tonge, Poiter. "The Abundance of the Oceans in INOT Iimited," The Christion Science Monitor, 65: 82:9, March 3, 1973.

- "Bring Furrows Yield Bumper Crops," The

Christian Science lionitor, 65:81:9, Warch 2, 1973.

- "Need Chickens izat Better Than People," The Christian Science lionitor, 65:80:7, March 1 , Is73.

- "Ocean Plenty: Fact or Mantasy," The Cluristian Science Ionitor, 65:79:7, February 28, 1973.

Toyinbee, Arnold. Cities on the llove. Oxford University Press, 1970. 
The Uizion of Concerned Scientists. "An ivaluation of Huclear ieactor Safety," Not Man Apart, Vol. II. San Francisco: Triends of the iarth, nugust 1972.

U.S. Department of Commerce. We, the Mmericans: Our Homes. Social and Iconoric Statistic Administration, Bureau of the Census, October 1972 .

U.S. Department of Transportation. 1972 National Transportation Report. liashington, D.C., 1972.

Uninh, Jesse $1 \%$ "To Bend the iind," The Futurist, April 1967, pp. 19-20.

Ventoules, Ted and Viard Eisenhauer, eds. Up Against the Urban Iiall. ITew Jersey: Prentice-HaII, 1971.

Walford, Lionel A. Living Resources of the Sea. INew York: The Ronald Press Company, 1958.

Waring, John. "The Horseporer Ixplosion," The Futurist, February 1969, pp. 23-24.

Westoff, Leslie and Charles S. From Now to Zero. New York: Little, Erom and Company, 1971.

Tilires, Paul. "When do We Have the Right to Die?" Iife, January 14, 1972.

Williams, Oliver P. and Charles Press. Democracy in Urban America. Chicago: Rand Nicilally, $1 \overline{909}$

Wilke, Dre and IIrs. J. C. Fandbook on Abortion. Cincinnati: Hiltz Fublishing, 1972 .

Wise, Villiam. Killer Smog. New York: Audobon/Ballantine Eook, 1970.

Wood, Robert. Suburbia, Its People and Their Politics. Boston: Houghton Mifflin, 1550.

Woodbury, C., ed. The Future of Cities and Urban Redevelopment. Chicago: University of Chicago Press, 1953.

Wright, iTathan, Jr. Black Pover and Urban Unrest. ITew York: Harthorn, 1972 .

Wrong, Dennis H. Population and Society . Wew York: Randon House, 1906.

Zero Population Grouth, Inc. "Zero Population Growth," Pamphlet. 
ANOHYMOUS (AIphabetized by Title of Article)

"Abortion Lar Attack Gains," The Washington Post, Nitovember $11,1969$.

"Abortions: Iioves to Abolish All Legal Restraints," The New York Times.

"The Advant of Big Biology," Time, March 23, 1970, p. 40.

"Advertising: Media Wary of Contraceptive," New York Times, iviarch 11, 1970.

"Agricultural Projections for 1975 and 1985, United States," Paris: OGCD, 1968.

"Aust Urges Freevay Studies," Omaha World-Herald, August 13, 1972 .

"Big Metropolitan Areas Get Bigger," The Futurist, October 1970 , p. 155.

"Billions for Urban Renewal -- But Iot Inough to Go Around," U.S. News and World Report, April 20, 1970, pp. 27-28.

"Bostash, Chipitts and Sansan," The Futurist, February 1968.

"Building a City in the Ocean," The Futurist, June 1969, pp. $66-69$.

"Building Utopia in Virginia," The Futurist, December 1967, pp. 86-87.

Cities. Hew Iork: \& Scientific American Book, 1966.

"Cities of the Future," The Futurist, June 1969, p. 67.

"Cities Till love Underground," The Futurist, June 1968, p. 54.

"City of the Future," The Christian Science rionitor, September 9, 1968 .

"Congress and Urban Mass Transportation," Congressional Digest, 48:289, December 1969.

"Conservation Caretaker," Time, February \&, 1970.

"The Conservation Coalition," Congressional Quarterly, 1971, p. 81 .

"Coping with Urban Spratl," The Futurist, October 1970. 
"Crowding Out," Washington Post, February 27, 1970.

"Ilectric and jolar Power Consurption Nrey Pise," The ruturist, tiubust 1967.

"Jndorsing Infonticide?" Time, Tiay 28, 1973, p. 104.

"Inergy and the Invironment," (speech) MBAA lieeting in

Chicago, liay 1970.

"The Tnergy Crisis: Time for Action," Time, May 7, 1973, p. W4ff.

"4ú Pci. of Homes Fuilt Since 1950," Omaha viorld-Herald, Septernber 21, 1972.

"Frence Blames Accidents, Hcoholism, and Insecurity for Underpopulation," IJeu York Times, l:pril 13, IS70.

"Freevey of Dodge," Omaho iorld-Herald, Fiay 12, 1973.

"Getting There in 1995," Omaha Torld-Herald, April 18, 1573.

"Glimpse of the Home of Tomorrow" U.S. Hews and World ieport, 54, July 3, 156́7, pp. 88-50.

"Goals and Objectives Suggested bir Citizens at an Open lieeting of the Quelity Bnvironment Council and the Soil and iater Conservation Service," January 13, I973.

"Green Refuge in the kge of Machines," Iiterature Gazette, February 24, 1971.

"Teat Pollution -- or Inrichment," Industrial Research, July 1968.

"iere Comes the Smog," Newsweek, August 10, 1970, pp. S4-65.

"Iousing Study Head Disputes Aust Viev," Cmeha Vorld-Herald, Huģust 22, 1972.

"How to Pay for liass Transit," Eusinass Week, 2095:72, October 31, 19ós.

"Sow to stop Pollution," U.S. Nevs and Vorld Report, November 23, 1970, pp. 54-57.

"Latest lioves on Pollution Control," U.5. Nevs and iorld leport, Februery 2, 1970.

"Fontreal Tait: Will Iien Live in Buibles?" The Futurist, Februery 1967.

"Hev Bag on Cempus," Newsweek, December 1969, p. 72. 
"New Products -- Fish Protein," Sweden Ners, 6:6:14, 1972.

"IIixon Starts the Cleamup," Time, February 23, 1970, pp. 39-40.

"How a Boom in Devices to Fight Pollution," U.S. Hevs and World Report, August 31, 1970, pp. 43-44.

"Official: Relocation No Longer Problem," Omaha viorldHerald, tpril 17, 1973.

"Open-Space Towns," Christian Science Iionitor, October 10, 1969.

"Opposition to Breeder-Reactor liounts," The Envi ronmenta],

Vol. IV, Columbus, Ohio: Earthday Comittee of the

Ohio State University, October 1972.

"Payrolls and Pickerel in Miaine," Time, February 16, 1970, p. 52.

"Pig Power as Hotor Fuel is High-Octane, Honpolluting," Omaha World-Herald, April 22, 1973.

"A Plastic House in Your Future," Petroleuri Today, Fall 1968.

"The Politicians Know an Issue," Nerssweek, January 26, 1970, p. 33.

"Pollution: Growing Menace -- What U.S. Is Doing About It," U.S. News and Torld Report, June 8,1969 , pp. 40-43.

"Population will Strain Natural Resources," The Futurist, December 1969, p. 156.

"Rapid Transit Halts Freeway," Omaha World-Herald, November 29, 1571 .

"Rapid Transit Instead of Freeway?" Omaha World-Herald, April 21, 1971.

"Report on the Geosocial Revolution," Saturday Review, 50, September 16, 1967, pp. 31-32.

"Report on iNational Goals Research Staff Tovards a Balance Grorth, quantity with Quality," Vashington, D.C., 1970.

"The Return of the Returnables?" Newsireek, September 21, 1970, pp. 70-71.

"Saving the Farm -.. and the City," New York Times, September 5, 1972.

"Saving the Land," Time, riay 28, 1973, p. 96. 
19. CPI Txinenge Bibliography it 532

"Special Issue: Icopornography," Rodale's Environmental Lction bulletin, Vol. III. mmaus, Pennsylvania: Rodale Press, Inc.

"Step Foiward in Housing," Omaha Woild-Herald, Iiay 3, 1972.

"sing to Unleaded Gas: That's Ahead," U.S. Ners and Horld Repont, December 28, 1870.

"They Chose to be Childless," New Yori: Timss, March 23, 1970.

"Three-County ieport Holds Few Surprises," Cmaha iorld-Harald, Septeiniver 30, I970.

"Todey I Hilled liy Best irriena," Time, 85, fpril 23, 1565, pp. $74-74$.

"Tomorror's Decentralized Cities," 1ise Tuturist, June 1967, pp. $38-39$.

Toreid Balanced Grorth: Duantity with Ouality. Report

of the National Goals Research Stañ, July 4, 1970,

Tasinington, D.C.

"Transporttation for the Boswash Corridor," The Futurist, February 1972.

"Untangling Biz-City Trafic: The Big Push for Ilass Transit," U.S. IVews and Worla Report, Washington, D.C., 67:48, 1.12 25: 1970 .

"Urbanization: Past is Clearer than Future," The Futurist, October 1870, pp. 167-10́8.

"Utah International iines Coal, Iron, Copper and Uraniung" Investor's ieader, spril 4, 1873, pp. 1ú-1S.

"Villages on Ocean Floor Are Foreseen," The Futuirist, June 1970 , p. 93.

"Wrat's thead in Ilousing," U.S. Ners and iorld Peport, February 2, 1870, pp. 57-58.

"Tho Vill Otrn tire Bea," The Iuturist, June 1568, pp. 4l-44. "Wintertime Iini-Crisis," Netrsteels, Pebruary 15, 1971, pp. 73-74. 
20. CPL Ixchange Bibliography "if532

COUNCIL OF PLAINING LIBRARIAISS EXchenge Bibliography it/532

\author{
A SOCIAL ECOLOGICAL
}

\title{
BIBLIOGRAPHY
}

Liditional copies available from:

Council of Planning Libreriens

Post Office Box 225

IMonticello, IIlinois 61856 

UNIVERSITY OF ILLINOIS-URBANA

29.

EXCHANGE BIBLIOGRAPHY, URBANA, ILL

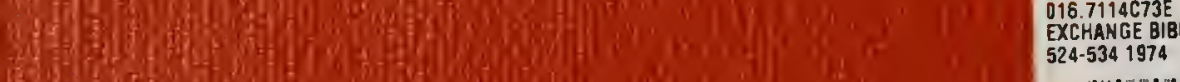

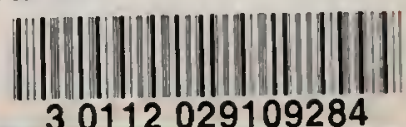

(1) 